\title{
A Study of Angiotensin Converting Enzyme (ACE) Gene Polymorphism in Essential Hypertension among a Business Community in Punjab
}

\author{
Badaruddoza, A.J.S. Bhanwer, R. Sawhney, N.K. Randhawa, K. Matharoo and B. Barna \\ Department of Human Genetics, Guru Nanak Dev University, Amritsar 143 005, Punjab, India
}

KEYWORDS ACE Polymorphism. Hypertension. Bania Population. Punjab

\begin{abstract}
The present study was carried out to investigate the association of the angiotensin -converting enzyme deletion/insertion polymorphism with hypertension and its role in increasing the susceptibility to hypertension among Bania population in Punjab. The study blood samples consisted of 50 normal (28 males and 22 females) healthy individuals and 50 hypertensive, age and sex matched (28 males and 22 females) individuals. The genotype frequencies were found to be $0.22,0.32$ and 0.46 for II, DD, ID genotype in hypertensives. The same has been found for normotensives to be $0.26,0.18$ and 0.56 for II, DD and ID respectively. The observed overall genotype distributions were consistent with Hardy-Weinberg equilibrium. The present analysis suggested that the genetic variation at the ACE gene may be associated with some determinants for blood pressure.
\end{abstract}

\section{INTRODUCTION}

Many studies have demonstrated the genetic linkage between ACE gene and blood pressure variations (Jeunemaitre et al. 1992; Chiang et al. 1996; Nakano et al. 1998; Ashavaid et al. 2000; Cox et al. 2002; Morshed et al. 2002). Despite of the fact that significant positive association of ACE gene with hypertension has been reported by many authors. However, many other studies (Dura et al. 1994; Barley et al. 1996; O’Donnell 1998) have failed to identify such associations. It has been suggested (Barley et al. 1994; Stassen et al. 1997) that this inconsistent association may be due to the fact of different ethnicity of the population groups and environmental heterogeneity. Therefore, it is of interest to study regarding the deletion/ insertion (D/I) polymorphism of ACE gene and blood pressure regulation. Hence, the present study was carried out to investigate the association of I/D polymorphism of ACE gene with hypertension and its role of increasing the susceptibility of hypertension among Bania population in Punjab.

\section{MATERIALS AND METHODS}

The study included a total of 100 individuals

Corresponding author:

Dr. Badaruddoza

Department of Human Genetics, Guru Nanak Dev

University, Amritsar-143005, Punjab, India

E-mail: doza13@yahoo.co.in of both sexes, consisting 50 each age and sex matched controls and patients with hypertension. These individuals were selected from the Bania community in Punjab. This community is mostly engaged in business and trade. They are primarily vegetarians and non-alcoholic. However, many male members of the family prefer alcoholic drink time to time. They are living in patrilocal society with by and large nuclear family system in single household sharing both genes and environment. The age ranges of selected subjects are between 40 to 70 years.

Blood pressure was measured using a mercury sphygmomanometer in a sitting position on with the right forearm placed horizontal on the table, as recommended by the American Heart Association (1981). All efforts were made to minimize the factors which may influence blood pressure. Hypertension was defined as systolic blood pressure $>140 \mathrm{~mm} \mathrm{Hg}$ accompanied by diastolic blood pressure $>90 \mathrm{~mm} \mathrm{Hg}$. None of the subjects had evidence of cardiac or renal diseases. About $5 \mathrm{ml}$ of peripheral blood samples were collected in a pre-labeled screw cap vial containing $20 \%$ EDTA. The specimens were transported from the place of collection to the laboratory on dry ice and were then stored at $-20^{\circ}$ $\mathrm{C}$ till further analysis. DNA was isolated from whole blood using standard protocol of Gill et al. (1987). To determine the ACE genotype, genomic DNA samples were amplified by a polymerase chain reaction (PCR) using primer pair such as 5'CTG GAG AGC CAC TCC CAT CCT TTC T-3' 
(sense) and 5' GAC GTC GCC ATC ACA TTC GTC AGA T 3' (antisense). The PCR reaction mixture contained $100 \mathrm{ng}$ genomic DNA, $0.2 \mu \mathrm{M}$ of each primer, $200 \mu \mathrm{M}$ dNTP, $10 \mathrm{mM}$ of Tris-HCL buffer (PH 8.3), $1.5 \mathrm{mM} \mathrm{Mgcl}_{2}$ (PH 8.3) and 0.024 units of Taq polymerase enzyme in a final reaction volume of $15.0 \mu \mathrm{l}$. After initial denaturation at $95^{\circ}$ $\mathrm{C}$ for 5 minutes, the DNA was amplified by 30 cycles of denaturation at $94^{\circ} \mathrm{C}$ for 45 seconds, annealing at $56^{\circ} \mathrm{C}$ for 45 seconds and primer extension at $72^{\circ} \mathrm{C}$ for 45 seconds. Final extension was performed at $72^{\circ} \mathrm{C}$ for 10 minutes. The amplified PCR products were separated by electrophoresis on $2 \%$ agarose gel and the DNA was visualized under UV transilluminator after staining with ethidium bromide. The insertion (I) allele was detected as band of $490 \mathrm{bp}$ fragment and deletion (D) allele was identified as a band of $190 \mathrm{bp}$ fragment. All the data were analyzed by SPSS 10.0. Two- tailed probability levels for statistical significance are reported. The relevant null hypothesis on odds ratio (Matched Pairs) in the present case is tested $\mathrm{H}_{0}: \mathrm{OR}_{\mathrm{M}}=1$.

\section{RESULTS}

Anthropometric and physiometric characteristics of the control and hypertensive subjects are presented in table I. The two study groups were well matched for sex, age and sample size. The mean systolic (SBP) and diastolic (DBP) blood pressures, BMI and WHR were significantly higher $(\mathrm{P}<0.001)$ among hypertensive subjects than in control subjects. However, there is no significant mean age difference between both groups. The ACE genotype and allele frequencies distribution of control and hypertensive subjects are shown in table 2 . The frequencies of II, ID and DD genotype among the control group were $26 \%(n=13), 54 \%(n=27)$ and $20 \%(n=10)$ respectively, whereas, in hypertensive group the same were found to be $22 \%(n=11), 32 \%(n=16)$ and $46 \%(n=23)$ respectively. There is significant difference $(p<0.05)$ observed in the distribution of ACE genotype polymorphism between the two groups. It has been observed that the ACE DD genotype was significantly $(\mathrm{p}<0.05)$ higher in hypertensive subjects, whereas, ID genotype was significantly $(p<0.05)$ higher in control subjects. The frequency of the D allele is also more frequent but not significant in hypertensive subjects than in control. The distribution of genotype frequencies associations of ACE gene polymorphisms between male and female among control and hypertensive subjects are given in table 3 . The results showed that among three genotypes within control group, ID genotype was significantly more prevalent in male as compared to other two genotypes (odds ratio:3.0; CI: 0.1525.84; $\left.\chi^{2}=14.0, \mathrm{P}<0.001\right)$. Whereas, among female, II genotype is comparatively more prevalent but not significantly differ (odds ratio: $0.692 ; \chi^{2}=1.45$, $\mathrm{ns})$. In the hypertensive group, both male and female are more associated with DD genotype as compared to other two genotypes. However, these

Table 1: Anthropometric and physiometric characteristics of the control and hypertensive subjects

\begin{tabular}{lccc}
\hline Variables & Controls $(n=50)$ & Hypertensive $(n=50)$ & $p$ \\
Mean $\pm S D$ & Mean $\pm S D$ & $\mathrm{~ns}$ \\
\hline Age (years) & $54.29 \pm 8.42$ & $54.25 \pm 9.03$ & $<0.001$ \\
BMI (Kg/m $\left.{ }^{2}\right)$ & $26.56 \pm 3.19$ & $29.32 \pm 3.25$ & $<0.001$ \\
WHR & $0.851 \pm 0.005$ & $0.971 \pm 0.006$ & $<0.001$ \\
SBP (mm Hg) & $129.31 \pm 10.13$ & $148.23 \pm 9.11$ & $<0.001$ \\
DBP $(\mathrm{mm} \mathrm{Hg})$ & $85.19 \pm 8.79$ & $92.14 \pm 7.37$ & \\
\hline
\end{tabular}

Table 2: Distributions of genotype and allele frequencies of ACE gene polymorphism in control and hypertensive subjects

\begin{tabular}{lrrr}
\hline Genotypes & $\begin{array}{c}\text { Controls }(n=50) \\
\text { Number }(\%)\end{array}$ & $\begin{array}{c}\text { Hypertensive }(n=50) \\
\text { Number }(\%)\end{array}$ & $p$ \\
\hline II & $13(26 \%)$ & $11(22 \%)$ & $\chi^{2}=8.11,<0.001$ \\
ID & $27(54 \%)$ & $16(32 \%)$ & \\
DD & $10(20 \%)$ & $23(46 \%)$ & \\
Alleles & & & $\chi^{2}=0.0032, \mathrm{~ns}$ \\
I & 0.51 & 0.47 & \\
D & 0.49 & 0.53 & \\
\hline
\end{tabular}


Table 3: Distributions of ACE genotypes between men and women

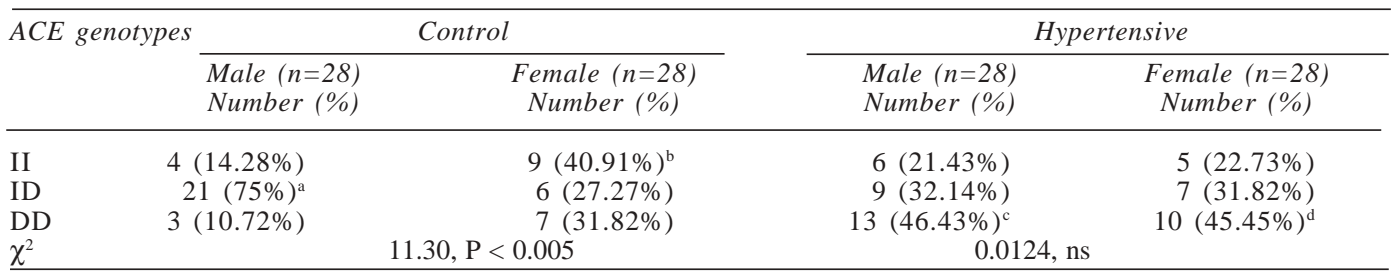

$\mathrm{ns}=$ not significant

ID against II + DD $\chi^{2}=14.0, \mathrm{P}<0.001, \mathrm{OR}=3.0(0.152-5.84)$

${ }^{b} \mathrm{II}$ against ID + DD $\chi^{2}=1.45, \mathrm{~ns}, \mathrm{OR}=0.692$

cDD against II + DD $\chi^{2}=0.286$, ns, OR=0.867

${ }^{\mathrm{d}} \mathrm{DD}$ against $\mathrm{II}+\mathrm{DD} \quad \chi^{2}=0.364, \mathrm{~ns}, \mathrm{OR}=0.833$

associations are not statistically significant (odds ratio $($ male $)=0.867 ; \chi^{2}=0.286, \mathrm{~ns} ;($ female $)=0.833$, $\left.\chi^{2}=0.364, \mathrm{~ns}\right)$.

\section{DISCUSSION}

In the present study, it has been investigated the association of ACE insertion/ deletion (I/D) polymorphism with hypertension among selected individuals from Bania (a business community) population in Punjab. The study was carried out between two groups (control and hypertensive) which were perfectly matched for age and sex. However, they were significantly different with respect to BMI, WHR, SBP and DBP. The study suggested a possible positive association of DD polymorphism with hypertension in Bania Population in Punjab. Many studies (Cambien et al. 1992; Tiret et al. 1993; Duru et al. 1994; Morise et al. 1994; Barley et al. 1996; Samani et al. 1996; Zaid et al. 1998; Turgay et al. 1999; Higaki et al. 2000) have reported positive ACE DD genotype association with hypertension. The frequency of $\mathrm{D}$ allele $(53 \%)$ in hypertensive group is more prevalent as compared to other allele between both the groups. Although, the difference is not significant $\left(\chi^{2}=0.0032, \mathrm{~ns}\right)$. In the present study, sex specific association of DD genotype with hypertension has not been seen. The possible reason for negative association of DD genotype with hypertension between both sexes may be relatively smaller sample size. However, it is interesting to note that in control group ID genotype was more significantly $(\mathrm{P}<0.001)$ associated with male, whereas, II genotype is more prevalent $(41 \%)$ in female though it is not statistically significant. Therefore, the present data suggest DD genotype have some association with hypertensive male and female individuals, although, the data did not show any statistical significance.

\section{ACKNOWLEDGEMENT}

The authors are sincerely thankful to Punjab Council for Science and Technology for providing financial assistance to Ms. Rashveen Sawhney (letter no. SSO/POS/ 80/2205 dated 30/3/07).

\section{REFERENCES}

American Heart Association 1981. Report of subcommittee of postgraduate education committee recommendations for human blood pressure determination by sphygmomanometer. Circulation, 64: 501A- 509B.

Ashavaid TF, Shalia KK, Nair KG, Dalal JJ 2000. ACE and AT1R gene polymorphisms and hypertension in Indian population. J Clin Lab Anal, 14: 230-237.

Barley J, Blackwood A, Carter ND, Crew DE, Cruickshank JK et al. 1994. Angiotensin converting enzyme insertion/deletion polymorphism: Association with ethnic origin. J Hypertens, 12: 955-957.

Barley J, Blackwood A, Miller M, Markandu ND, Carter ND et al. 1996. Angiotensin converting enzyme gene I/D polymorphism, blood pressure and the rennin-angiotensin system in Caucasian and AfroCaribbean peoples. J Hum Hypertens, 10: 31-35.

Cambien F, Poirier O, Lecerf L 1992. Deletion polymorphism in the gene for angiotensin converting enzyme is a potent risk factor for myocardial infarction. Nature, 359: 641- 644.

Chiang FT, Chem TH, Lai ZP, Tseng CD, Hsu KL, Lo HM, Tseng YZ 1996. Age and gender dependent association of the angiotensin-converting enzyme gene with essential hypertension in a Chinese population. J Hum Hypertens, 10: 823-826.

Cox R, Bouzekri N, Martin S, Southam L, Hugill A et al. 2002. Angiotensin-1-converting enzyme (ACE) plasma concentration is influenced by multiple ACElinked quantitative trait nucleotides. Hum Mol Genet, 11: 2969-2977.

Duru K, Farrow S, Wang JM, Lockette W, Kurtz T 1994. Frequency of a deletion polymorphism in the gene 
for angiotensin converting enzyme is increased in African-American with hypertension. Am J Hypertens, 7: 759-762.

Gill P, Lygo JE, Fowler SJ, Werett DJ 1987. An evaluation of DNA fingerprinting for forensic purpose. Electrophoresis, 8: 38-44.

Higaki J, Baba S, Katsuya T, Sato N, Ishikawa K et al. 2000. Deletion allele of angiotensin-converting enzyme gene increases risk of essential hypertension in Japanese men. Circulation, 101: 2060-2065.

Jeunemaitre X, Soubrier F, Kotelevtsev Y, Lifton RP, Williams CS, Charru A, Hunt SC, Hopkins PN, Williams RR, Lalouel JM, Corvol P 1992. Molecular basis of human hypertension: Role of angiotensinogen. Cell, 71: 169- 180.

Morise T, Takeguchi Y, Takeda R 1994. Angiotensin converting enzyme polymorphism and hypertension. Lancet, 343: 125.

Morshed M, Khan H, Akhteruzzaman S 2002. Association between Angiotensin I- converting enzyme gene polymorphism and hypertension in selected individuals of the Bangladeshi population. J Biochem Mol Biol, 35: 251-254.

Nakano T, Oshima T, Hiraga H, Matsuura H, Kajiyama G, Kambe M 1998. DD genotype of the angiotensin I-converting enzyme gene is a risk factor for early onset of essential hypertention in Japanese Patients. J Lab Clin Med, 131: 502-506.
O’Donnell CJ, Lindpainter K, Larson MG, Rao VS, Ordovas JM et al. 1998. Evidence for association and genetic linkage of the angiotensin-converting enzyme locus with hypertension and blood pressure in man but not women in the Framingham Heart Study. Circulation, 97: 1766-1772.

Samani N, Thompson JR, O' Toole L, Channer K, Woods KL 1996. A Meta analysis of the association of the deletion allele of the ACE gene with MI. Circulation, 94: 708- 712 .

Stassen JA, Wang JG, Ginocchio G, Petrov V, Saavedra AP et al. 1997. The deletion/insertion polymorphism of the angiotensin converting enzyme gene and cardiovascular-renal risk. J Hypertens, 15: 1579 1592 .

Tiret L, Kee F, Poirier O, Nicard V, Lecerf L. Evans AE, Cambau JP Arveiler D, Luc G, Amovyel P, Cambien F 1993. Deletion polymorphism in the ACE gene associated with parental history of MI. Lancet, 341: 991-992.

Tugray I, Hulya Y, Bedia A, Makbule A, Selim AI 1999. Association between angiotensin converting emzyme gene polymorphism and coronary artery disease. IUBMB Life, 48: 205-207.

Zaid AA, Wilso AC, Cosgrove NM, Kostis JB 1998. Angiotensin-Converting enzyme gene polymorphism in systemic hypertension. Am J Cardiol, 81: 244-246. 